\title{
Extracorporeal Membrane Oxygenation (ECMO) : New Technology or Just A New Tool for Developing Countries?
}

Iqbal Mustafa, Heru Samudro

\begin{abstract}
Abstrak
Manajemen pasien dengan ventilasi mekanik pada gagal napas akut dan / atau adult respiratory distress syndrome di negaranegara berkembang biasanya dilakukan oleh ahli anestesiologi. Di negara maju pun, gagal napas akut, terutama adult respiratory distress syndrome mempunyai mortalitas yang masih tinggi. Extracorporeal membrane oxygenator (ECMO) merupakan inovasi teknologi tinggi dalam bidang intensive care medicine yang dimulai sejak 20 tahun lampau. Pada beberapa unit perawatan intensif di negara maju, ECMO digunakan pada gagal napas akut sebagai rescue therapy atau sebagai terapi alternatif pada prediksi mortalitas tertentu. Di USA, ECMO telah merupakan terapi standar pada gagal napas neonatus. Hasil terapi ECMO berbeda-beda pada kelompok umur yang berbeda. Hasil terbaik didapat pada neonatus, yaitu dengan $70-90 \%$ berhasil dengan selamat, sedangkan pada anak dan dewasa, didapati mortalitas 45-55\% untuk pasien yang diprediksi mempunyai mortalitas sekitar $80 \%$ dengan ventilasi mekanik. Apakah mungkin dilakukan ECMO di negara berkembang? ECMO tidak dapat disangkal sangat efektif untuk terapi pada neonatus dengan gagal napas, tetapi ECMO sangat membutuhkan tenaga. Biaya ECMO juga sangat tinggi, kira-kira 2 kali terapi perawatan intensif standar. Dengan mempertimbangkan cost benefit analysis, ECMO tampaknya lebih baik dilakukan di negara-negara berkembang hanya pada rumah sakit tertentu yang mempunyai cukup pengalaman operasi jantung terbuka, dan hanya dilakukan pada gagal napas neonatus.
\end{abstract}

\begin{abstract}
The management of patient's mechanical ventilation, in acute respiratory failure and / or adult respiratory distress syndrome in developing countries is generally done by anesthesiologist. Even in developed countries, patients with acute respiratory failure and particularly adult respiratory distress syndrome have a very high mortality rate. Extracorporeal membrane oxygenation (ECMO) is an innovation of high technology in the intensive care medicine which emerged two decades ago. In certain centers in several developed countries, ECMO for acute respiratory failure is used as a rescue therapy or as an alternative therapy at a certain predicted mortality rate. In fact, in neonatal respiratory failure in the United States, ECMO is considered as a standard therapy. Unfortunately, the result of ECMO is different at different age groups. The best results is in neonates, i.e. 70-90\% survival rate, while for older children and adults the mortality rate is $45-55 \%$ for patients with predicted mortality rate around $80 \%$ with mechanical ventilation. Would it be possible to start ECMO therapy in developing countries? ECMO has been unquestionably successful in treating a large number of term infants with respiratory failure, but ECMO is very labor intensive. The cost for ECMO is very high, it is about twice as high as standard intensive care treatment. Taking into considerations the cost benefit analysis and cost effective analysis ECMO would be better carried out in developing countries only at certain hospitals with enough bypass or open heart surgery experience ( $1-2$ selected centers), and is best done only in neonatal respiratory failure.
\end{abstract}

Keywords: ECMO, Developing countries, Cost, Neonates

\section{HISTORY}

Extracorporeal membrane oxygenation (ECMO) is a form of invasive cardiopulmonary support that can provide temporary physiologic stabilization in reversible circulatory and/or respiratory failure. The history of ECMO application in clinical situation has been controversial. In essence, ECMO is an innovative

Intensive Care Unit, National Cardiac Centre Hospital, Jakarta, Indonesia intensive care unit application of operating room cardiac technology. The use of an artificial lung for extended applications was not considered a serious possibility until Kolf and Clowes, demonstrated that the interposition of a gas permeable membrane between the blood and gas greatly reduced both blood trauma and embolic accidents due to direct gas blood exposure in the heart lung machines then in use. ${ }^{1}$ Work with new fabrication and membrane materials and improved design concepts contributed to the steady evolution of membrane lungs through the 1950 s and early $1960 \mathrm{~s} .{ }^{2,3}$ Before the evolution of membrane 
oxygenator, oxygenation on cardiopulmonary bypass for heart surgery had been achieved with a bubble oxygenator which although providing an efficient gas exchange, caused injury to the cells at the blood/gas interface. This injury resulted in hemolysis and platelet destruction when cardiopulmonary was prolonged.

In 1972 Hill reported the first successful ECMO case; a 24- year old man with severe blunt thoracic trauma who was treated for four days with support using a membrane lung and veno-arterial bypass via the femoral vein and artery. Following this initial report of success, ECMO support become more widespread for patients with acute respiratory failure. At that time there were no clear indicators of the limits to which mechanical ventilation support could be used before ECMO was considered. ${ }^{4}$ Also the optimal ventilator setting, especially the setting for positive end expiratory pressure (PEEP), was significantly different from the setting that we accept today. 5

In view of the large number of anecdotal reports that had appeared in the medical literature, the National Heart Lung and Blood Institute supported a multicenter trial in severely ill patients with acute respiratory failure (ARF), ${ }^{3}$ comparing the efficacy of combined extracorporeal veno-arterial bypass and conventional continuous positive pressure ventilation (CPPV) with CPPV alone. The trial involved nine centers which together enrolled 90 patients during 2.5 year period The entry criteria were: ${ }^{3}$ The fast entry criteria, which included patients with a $\mathrm{PO}_{2}$ of $<50$ $\mathrm{mmHg}$ for more than two hours when ventilated with a fraction of inspired oxygen ( $\left.\mathrm{FIO}_{2}\right)$ of 1,0 and positive end expiratory pressure (PEEP) of $5 \mathrm{~cm} \mathrm{H}_{2} \mathrm{O}$ or greater; the slow entry criteria which include, patients with a $\mathrm{PaO}_{2}$ of $50 \mathrm{mmHg}$ for more than 12 hours when ventilated with a $\mathrm{FIO}_{2}>0,6$ and $\mathrm{PEEP}>5 \mathrm{~cm} \mathrm{H} 2 \mathrm{O}$, and intrapulmonary shunt $30 \%$ of cardiac output when measured at $\mathrm{FIO}_{2}$ of 1,0 . Eligible patients had to be $>12$ years and $<65$ years and patients were excluded if the pulmonary insult was longer than 21 days duration, if the wedge pressure was $>25 \mathrm{mmHg}$, or if there was chronic or irreversible disease in other organ system. In both groups of patients the mortality rate was approximately $90 \%$ and there were no difference between the groups. The observed mortality of $90 \%$ was disappointing and unexpected.

This finding led to loss of enthusiasm for the use of ECMO support in acute respiratory failure (ARF). But this trial did demonstrate that extracorporeal support can be provided safely for prolonged period of time. The main rationale behind the ECMO study was to correct hypoxemia and "buy time" for spontaneous healing of lungs. Veno-arterial bypass was chosen over veno-venous bypass because of the better arterial oxygenation and the lower intrapulmonary shunt achieved through veno arterial bypass. ${ }^{2}$

However the validity of the result has been criticized because of the study design. Reading the details of the study in the 1990s, most people would consider that the limits of conventional treatment defined in this study, especially the level of PEEP that was used, are very different from those acceptable today when it is not unusual to use levels of PEEP up to $20-25 \mathrm{cmH}_{2} \mathrm{O}$ in the most severe cases.

Also in the last 20 years, there have been many significant advances in the technology of extracorporeal circulation. Consequently, the complications associated with untoward events such as tubing rupture, bleeding, hemolysis have been considerably reduced. ${ }^{5,6}$ Also, the deleterious effects of CPPV on hypoperfused lung tissue were probably underestimated and the concept of "buying time" was applied in a lung environment that was not optimum for pulmonary repair and recovery. ${ }^{7,8}$

In 1976, Gattinonni from Milan Italy tested in their laboratory a new artificial lung, especially designed for carbon dioxide removal, for possible clinical use in hypercapneic patients. They have found that extracorporeal $\mathrm{CO}_{2}$ removal $\left(\mathrm{ECCO}_{2} \mathrm{R}\right)$ is an effective technique for control of ventilation in animals. Also they found that it was possible to decrease mechanical ventilation to zero while providing a continuous oxygen flow (apneic oxygenation) equal to the oxygen consumed and that the use of low frequency positive pressure ventilation of $3-4$ breaths per minute at limited peak pressure avoid the progressive atelectasis formation observed during apnea. $5^{5}$

With that finding an era of application of $\mathrm{ECCO}_{2} \mathrm{R}$ with continuous low frequency positive pressure ventilation (LFPPV) has come; the hypothesis is that this technique could promote healing of the lungs by avoiding the deleterious effects of high volume high pressure ventilation. $^{6,9}$

\section{TERMINOLOGY}

The term ECMO (extracorporeal membrane oxygenation) refers to high flow veno-arterial bypass. Venoarterial (VA) bypass will also support the circulation/ failing heart, but it is associated with a relative lung hypoperfusion. The term extracorporeal $\mathrm{CO}_{2}$ removal $\left(\mathrm{ECCO}_{2} \mathrm{R}\right)$ refers mainly to veno-venous access with 
an extracorporeal blood flow ranging between $20 \%$ and $30 \%$ of the cardiac output. Partial extracorporeal $\mathrm{CO}_{2}$ removal $\left(\mathrm{PECO}_{2} \mathrm{R}\right)$ indicates a very low flow vein to vein circulation with only partial removal of the $\mathrm{CO}_{2}$ produced (30-60\%). Japanese clinicians have used the term extracorporeal lung assist (ECLA) to describe a technique similar to $\mathrm{ECCO}_{2} \mathrm{R}$. The term ECLA or ECCRS (extracorporeal respiratory support) generally refer to the use of a membrane lung without emphasizing any specific objective (oxygenation, or $\mathrm{CO}_{2}$ removal). ${ }^{10}$ The above confusion in terminology originated from the initial attempts at emphasizing oxygenation as the main goal in the use of the membrane lung. High flow a-v bypass (ECMO) not only improves oxygenation, but also removes all $\mathrm{CO}_{2}$ produced, and provides full cardiac output. Venovenous bypass $\left(\mathrm{ECCO}_{2} \mathrm{R}\right)$ removes $\mathrm{CO}_{2}$ efficiently and provides oxygen in an amount roughly proportional to the ratio of extracorporeal blood flow to the cardiac output, but offers no support of the heart.

Whatever terminology is used, a correct description of the system must include: ${ }^{11}$

1. The type of bypass ( $\mathrm{V}-\mathrm{A}$ or $\mathrm{V}-\mathrm{V}$ )

2. The ratio of the extracorporeal blood flow (ECBF) to the cardiac output, which is essential to understand the contribution of the system to the oxygenation

3. The ventilatory management of the natural lungs.

PRINCIPLES OF GAS EXCHANGE, ADVANTAGES / DISADVANTAGES OF DIFFERENT TECHNIQUES

Oxygenation with ECMO is accomplished via the membrane lung. Oxygen diffuses from the fresh gas supplied across the membrane to the lung. The amount of oxygen that can be transferred across the membrane lung is limited by: ${ }^{12}$

a. The permeability of the membrane

b. Surface of the membrane

c. Blood flow through the membrane.

Varying the fraction of $\mathrm{O}_{2}$ in the flow gas to attain a post oxygenator $\mathrm{PO}_{2}$ of $100-200 \mathrm{mmHg}$ provides adequate arterial oxygenation. To increase oxygen delivery and raise $\mathrm{P}_{2}$ blood flow through the oxygenator must be increased. This both increases the amount of blood oxygenated via the membrane and decreases blood flow to the patients poorly functioning lung. The silicone membrane lung is highly permeable to $\mathrm{CO}_{2}$ and is very efficient at $\mathrm{CO}_{2}$ removal. $\mathrm{CO}_{2}$ removal is done by increasing the rate of gas sweeping across the membrane or by decreasing the concentra- tion of $\mathrm{CO}_{2}$ in the sweep gas (some centers add $\mathrm{CO}_{2}$ to the inflow gas) to increase the gradient between blood and oxygenator inflow gas. ECMO can be used for 2 basic physiologic functions:

a. To process blood, removal of $\mathrm{CO}_{2}$ and saturation it with oxygen, replacing the lungs.

b. To bypass the heart, by taking venous blood at low pressure and reinfusing it into the aorta at high pressure.

During veno-venous bypass or $\mathrm{ECCO}_{2} \mathrm{R}$ (extracorporeal $\mathrm{CO}_{2}$ removal) about $70-80 \%$ of oxygenation occurs through the natural lung. The amount of oxygen provided by the membrane lung depends on the extracorporeal blood flow, hemoglobin (concentration and saturation) and the amount of oxygen of the gas mixture. During routine perfusion, the extracorporeal blood flow ranges between $20 \%$ and $30 \%$ of the cardiac output, and the fraction of oxygen consumption provided by the membrane is about the same. Extracorporeal blood flow and oxygen can be increased to provide total respiratory support. A high blood flow and $0_{2} 100 \%$ from the gas mixture can maintained life for days without gas exchange in the natural lung. Clearance of the total $\mathrm{CO}_{2}$ minute production (200-400 $\mathrm{ml} / \mathrm{min}$ ) requires a blood flow of 1,5 to $2,51 / \mathrm{min}$ and 15 to $20 \mathrm{l} / \mathrm{min}$ of ventilation. The $\mathrm{CO}_{2}$ clearance is less dependent on extracorporeal blood flow; the key factor for $\mathrm{CO}_{2}$ clearance is the surface area of the membrane lung (a $9 \mathrm{~m}^{2}$ surface is usually required to provide adequate $\mathrm{CO}_{2}$ removal in an adult patient). ${ }^{13}$ It is occasionally impossible to institute "complete" venoarterial bypass because of other mechanical factors. However the advantages of complete veno-arterial bypass are reduced cardiac work load and assurance of circulatory adequacy, good arterial oxygenation, complete dissociation of lung function and gas exchange, good estimation of oxygen delivery and consumption based on known pump flow and delivered oxygen content of the arterial blood. Also it allows the inspired oxygen tension to be reduced, largely withdraw the ventilatory support and minimizing barotrauma. 13,9 Partial ECMO allows some of the venous return to pass through the lungs. This blood remains desaturated as long as the disease persists. When partial ECMO is achieved using femoral arterial access, coronary and brain oxygen delivery are uncertain. Some pulmonary gas must be maintained when ECMO support is not complete.

Veno-venous bypass is generally presumed to minimize the incidence of embolic central nervous system injury because it does not require cannulation of the arterial system. Only $30 \%$ of the venous return can be 
captured by the venous cannula during veno-venous bypass. The pump output is directed to the pulmonary circulation allowing some gas exchange. The pulmonary arterial oxygen levels are elevated although remain below the desired systemic arterial oxygen level. Reliance on pulmonary gas exchange therefore is reduced but not eliminated. Veno-venous bypass has been used to dissociate the carbon dioxide elimination from oxygen uptake. Apneic oxygenation (passive diffusion) is sufficient to support oxygen uptake by the lungs. Pulmonary ventilation is not required if venovenous or partial veno arterial bypass is used to clear carbon dioxide at the rate it is produced by the body. ${ }^{11}$ Again with this technique barotrauma is reduced. The limitation of this approach is that reduced ventilation and pulmonary distending pressure may allow the diseased lung become more atelectatic and less capable of apneic oxygenation. This problem is usually overcome by maintaining the positive end expiration pressure.

\section{TECHNIQUES}

\section{Veno-arterial bypass}

This is a standard technique currently used in neonatal respiratory failure, and it is also increasingly used in pediatric population with circulatory failure. ${ }^{14}$ The first step is to prepare the ECMO circuit, which is done by removing air from the circuit, and then primed the circuit with red blood cell and albumin (to decrease platelet adhesion). Normal acid base status in the circuit is attained by buffering the circuit with sodium bicarbonate. The cannulation is done under general anesthesia by a surgeon. A venous drainage cannula $10-14 \mathrm{~F}$ is placed surgically into the right internal jugular vein and advanced to the right atrium. A second cannula $(8-10 \mathrm{~F})$ is placed into the right common carotid artery and advanced to the ascending aorta. 150 $\mathrm{u} / \mathrm{kg}$ of heparin is given as an initial intravenous bolus. The ECMO circuit and cannula are carefully connected to ensure that no air has been introduced into the system. Bypass is begun by removing clamps and slowly increasing the flow until $300-400 \mathrm{ml} / \mathrm{min}$, which maintains cardiac output at about $70-80 \%$ of its estimated $140-150 \mathrm{ml} / \mathrm{kg}$ average in neonatus. ${ }^{12}$

\section{Veno-venous bypass}

This technique is used mainly in adult respiratory failure. In the beginning a femoral jugular bypass is used with two catheters surgically inserted proximally and distally in the femoral and two in the jugular veins. Due to heavy bleeding from the wounds, a single vein bypass was used for access into the common femoral vein. Extracorporeal circulation was obtained entirely via single double lumen catheter, with the outer lumen used for drainage and the inner for return of the blood to the patient. A modified and simple technique is the sapheno-saphenous vein technique. The blood is drained via a catheter advanced into the femoral vein from the saphenous vein on one side and is returned through the saphenous vein on the other side. Oozing from the surgical cutdowns was a constant source of bleeding in the anticoagulated patient $(50 \%$ of the total blood loss). ${ }^{6}$ Percutaneus cannulation of the femoral or jugular vein is now popular, and catheters up $29 \mathrm{~F}$ or even $34 \mathrm{~F}$ are available allowing total $\mathrm{CO}_{2}$ removal (blood flow up to 3 to $4 \mathrm{l} / \mathrm{min}$ ). The catheters are easily inserted and the risk of bleeding is negligible. Difficulty in maintaining adequate flow and oxygenation, combined with venous drainage problems in the distal limb, have limited the use of veno venous bypass in infants although some centers have had success in other pediatric patients. A double lumen catheter providing both venous drainage and oxygenated return to the internal jugular vein, is being used in some centers. $^{12,15}$

\section{ENTRY CRITERIA}

\section{Neonates}

The original criteria for the selection of babies for ECMO treatment were based on institutional review that identified infants with a greater than $80 \%$ predicted mortality if treated with mechanical ventilation. A retrospective review by those institutions provided ventilation parameters and blood gas values that accurately identified this high mortality group. 16 The present eligibility criteria for babies are: ${ }^{7,18}$

1. Birthweight $>2 \mathrm{~kg}$; Gestation $>35$ weeks

2. Absence of intraventricular hemorrhage (outside germinal matrix, > Grade I).

3. Absence of severe and uncorrectable coagulopathy

4. Absence of congenital anomalies incompatible with life.

This infant must be without lethal congenital anomalies, central nervous system abnormalities or coagulation disturbances that precluded the use of heparin. Because of the high incidence of intraventricular hemorrhage in the pre-term neonate, ECMO is used only for infants more than 35 weeks gestational age and more than $2 \mathrm{~kg}$ birth weight. This effectively excludes most pre-term infants with the infant respiratory distress syndrome. Usual criteria used to predict which patients are likely to die from their respiratory failure are: ${ }^{19,20}$ 
a. Oxygenation Index (Mean Airway Pressure $x$ Fi02x 100/Pa02)

0I $>40$ indicates a greater than $80 \%$ mortality OI $>25<40$ indicates a mortality of $50-80 \%$.

b. A-aD02 (Alveolar arterial difference of partial pressure of oxygen).

$\mathrm{A}-\mathrm{aD} 02>610 \mathrm{mmHg}$ for 8 consecutive hours or $605 \mathrm{mmHg}$ for 4 consecutive hours at a peak airway pressure of $38 \mathrm{cmH} 20$.

c. Unresponsiveness

$\mathrm{Pa} 02<55 \mathrm{mmHg}$ and $\mathrm{pH}<7.40 \times 3 \mathrm{hr}$

d. Acute Deterioration

$\mathrm{Pa} 02<40 \mathrm{mmHg}$ for $>2$ hours and or

$\mathrm{pH}<7.15$ for $>2$ hours.

$\mathrm{Pa} 027<55 \mathrm{mmHg}$ and $\mathrm{pH}<7.4$ for 3 hours.

\section{Older Children (1 month - 18 years)}

Little is known about factors predicting death in pediatric respiratory failure. Indications for instituting ECMO were derived from the neonatal experience or using the NIH ECMO study criteria combined with a intra pulmonary shunt $>30 \%$ when measured at an $\mathrm{FIO}_{2}$ of 1.0 and positive end expiratory pressure of $5 \mathrm{cmH}_{2} \mathrm{O}$.

\section{Adult}

\section{$\mathrm{ECCO}_{2} \mathrm{R}$ (Extracorporeal $\mathrm{CO}_{2}$, Removal)}

The entry criteria for $\mathrm{ECCO}_{2} \mathrm{R}$ in adult also are mainly based on gas exchange values during standard ventilatory conditions, and the $\mathrm{NIH}$ ECMO study criteria is still used. But nowadays additional parameters such as lung mechanic, pulmonary hemodynamic and even lung imaging are used. Gattinoni introduced criteria based on gas exchange, poor CT scan response to increasing levels of PEEP (as evidenced on CT Scan with overinflation of ventilated lung areas rather than recruitment of new alveoli) and compliance lower than $30 \mathrm{ml} / \mathrm{cmH}_{2} \mathrm{O}\left(0,5 \mathrm{mg} / \mathrm{kg}, \mathrm{cm}-\mathrm{H}_{2} \mathrm{O}\right)$ for patients to be selected to undergo extra corporeal life support. ${ }^{5}$ Recently Anderson also use the NIH-ECMO study criteria, compliance criteria, and used pulmonary shunt more than $30 \%$ or carbon dioxide tension greater than $44 \mathrm{mmHg}$ after and despite optimal ventilator and pharmacologic therapy as an indicator for severity of disease. Thirty percent shunt correspondence to arterial oxygen saturation less than 0,95 at an inspired oxygen fraction of 1,0 and a venous oxygen saturation $<0,65$. Potential for reversible disease was defined as age less than 60 years, days of mechanical ventilation less than 6 days, and no pharmacologic immunosuppresion. ${ }^{6}$
Absolute contraindications were terminal disease or severe neurologic impairment, active bleeding prohibiting acute anticoagulation, and mechanical ventilation for more than 10 days. Optimal ventilator therapy was defined as the lowest inspired oxygen fractionsufficient to maintain arterial saturation greater than 0,95 , optimal positive end expiratory pressure and peak inspiratory pressure based on highest mixed venous oxygen saturation, and rate adjusted to maintain carbon dioxide tension at $40 \mathrm{mmHg}$ or less without exceeding a peak inspiratory pressure of 50 $\mathrm{cmH}_{2} 0{ }^{6,21}$ Other authors also use the old NIH criteria but put additional criteria like Murray score $>2,5$ and failure to improve respiratory parameters with different modes mechanical ventilation (Brunet), and $\mathrm{PaO}_{2} / \mathrm{FIO}_{2}<150 \mathrm{mmHg}, \mathrm{PEEP}>10 \mathrm{cmH}_{2} \mathrm{O}$, (fast entry): maximum medical therapy for $24-120 \mathrm{~h}$ $\mathrm{PaO}_{2} / \mathrm{FIO}_{2}$ û $\mathrm{mmHg}, \mathrm{PEEP} 10 \mathrm{cmH}_{2} \mathrm{O}$, Qs/Qt $>30 \%$ at FIO $210, \mathrm{CtSat}<30 \mathrm{ml} / \mathrm{cmH}_{2} \mathrm{O}$ or recurrent barotrauma. ${ }^{22}$

$\mathrm{PaO}_{2}=$ partial pressure if arterial oxygen

$\mathrm{FIO}_{2}=$ fraction of inspired oxygen

Qs/Qt = intrapulmonary shunt

PEEP = positive end-expiratory pressure

Ctslat = static compliance on CT scan

\section{GENERAL MANAGEMENT}

At the beginning of the bypass the $\mathrm{FIO}_{2}$ and the mean airway pressure are maintained at pre bypass level to prevent sudden lung collapse or edema. When blood gases start to improve, oxygen ventilating the lungs and the membrane lungs are decreased progressively. The whole system is monitored, and in adult $\mathrm{ECCO}_{2} \mathrm{R}$ with catheter sizes up to $29 \mathrm{~F}$ the blood flow of $3-41 / \mathrm{m}$ can be delivered. PEEP level should be reduced hourly cautiously. The lungs are ventilated three to four times per minute in limited pressure mode $\left(34-45 \mathrm{cmH}_{2} 0\right)$, the low frequency is maintained until lung improves. ${ }^{5}$ With further improvement, anesthesia and paralysis are suspended and the patient is allowed to breath spontaneously (in pressure support, intermitent mandatory ventilation or continuous positive airway pressure). There is a tendency to use pressure support ventilation (supported spontaneous respiration) at a much earlier stage and therefore a rather long period (more than 3 weeks) is spent in partial extra corporeal $\mathrm{CO}_{2}$ removal. During this time variable proportions of the $\mathrm{C}_{2}$ load are eliminated by the membrane and the natural lung. During these long bypasses (days or weeks) very often the gas exchange fraction of the natural lung is totally lost. This will require blood flows as high as $4-51 / \mathrm{m}$ to warrant a $\mathrm{PaO}_{2}$ of $50 \mathrm{mmHg}$ (total extracorporeal gas exchange). ${ }^{23}$ The patient's 
lung may be so diseased as to reach zero gas exchange for weeks and still achieve total recovery. The general management of $\mathrm{ECCO}_{2} \mathrm{R}$ patient (antibiotics, nutrition, water balance) is no different from other critically ill patients. The patient is disconnected when his blood gases remain normal for 4-12 hours (with $\mathrm{FIO}_{2}$ of 0,4 ) without extracorporeal gas exchange (gas lines clamped). ${ }^{5}$

In neonates once the canulla are in place flow is initiated at about $50 \mathrm{cc} / \mathrm{min}$ and increased in increments in $50-100 \mathrm{cc}$ to approximately $100-120 \mathrm{cc} / \mathrm{kg} / \mathrm{min}$. This correspondence to about $80 \%$ of the cardiac output. The ventilator settings gradually are reduced to an $\mathrm{FIO}_{2}$ of 0.21 , a peak inspiratory pressure of $15 \mathrm{cmH}_{2} \mathrm{O}$, and a positive end expiratory pressure of $5 \mathrm{cmH}_{2} \mathrm{O}$. Inotropic drugs such as dopamine and vasodilator gradually are discontinued. Hemoglobin, hematocrit, platelets, WBC, electrolytes and calcium are monitored every 8 hours. ${ }^{24}$

Typically an infant on ECMO will need $4 \mathrm{mEq} / \mathrm{kg}$ of sodium and 50-70 daily. Due to the sequestration of platelet into the membrane avoid transfusing degradation products from the plasma supernatant. Ultrasound is done daily to detect intracranial hemorrhage. Echocardiography studies can be done to provide information on chamber volume, myocardial function and central shunts.

Lung rest for 48 hours can be done and usually allows an ruptured parenchyma (which cause a persistent air leak) to heal. Lung reinflation is accomplished with mild lavage to remove accumulated secretions, several minutes of hand ventilation and then returned the patient to low ventilator settings. Modifying ventilator settings has little effect on blood gas tensions or acid base balance. Oxygenation is improved by increasing flow from the pump, which in turn depends on the amount of blood available for drainage to the circuit, the internal diameter of the venous cannula, proper cannula position, and bed elevation over the ECMO system. If the cannula is correctly positioned in the right atrium, increasing pump flow generally requires administring blood components or fluid. A kinked cannula, pericardial effusion, or increased intrathoracic pressure secondary to pneumothorax or pneumocardium may also impede venous return.

All intravenous solution can be administred through the ECMO circuit. Initial fluids are kept at 120 $\mathrm{ml} / \mathrm{kg} /$ day and can be increased to $140 \mathrm{ml} / \mathrm{kg} /$ day. Because of the heparinization all invasive procedures are avoided. If there is a need for central lines it should be inserted before the heparinization. Special care is used when entering the system. One port is used for injection and one for withdrawal only, to reduce the risk of nosocomial infection. Daily chest $\mathrm{x}$-rays are obtained to follow progression of the lung disease and to check for changes in catheter position. $95,25,26$

\section{OUTCOME}

\section{Adults}

As it has previously discussed the high mortality of NIH ECMO study (90\%) has changed since Gattinoni introduced the $\mathrm{ECCO}_{2} \mathrm{R}$ technique. In 1986 they reported $48 \%$ survival rate in 43 ARDS patients. To date more than 300 patients in different European centers have undergone $\mathrm{ECCO}_{2} \mathrm{R}$ for severe $\mathrm{ARDS}$ and the survival rate is $46 \%$ (mortality around $50 \%$ ). ${ }^{22}$ Also in US ECMO/ $\mathrm{ECCO}_{2}$ has taken place again as a way of extracorporeal respiratory support. Anderson describes succesfull treatment of $50 \%$ of 10 patients with severe adult respiratory distress syndrome.

\section{Children (1 month-18 years)}

In the '70s experiences of ECMO in non-neonatal pediatric respiratory failure are limited. However in the last 5 years, following success in the neonatal population, the numbers of $\mathrm{ECMO} / \mathrm{ECCO}_{2} \mathrm{R}$ intervention in pediatric patients increased dramatically. In US alone as of August 1991, 220 pediatric patients meeting entry criteria were reported having recieved $\mathrm{ECMO} / \mathrm{ECCO}_{2} \mathrm{R}$ for severe pulmonary failure, with a survival rate of $46 \%$ in the cummulative population. However, a statistically significant difference between era before and after January 1989 was observed with the recently treated group having a greater survival rate (52\% vs. $30 \%$ ). An analysis of this 220 pediatric patients has established variables measured before the initiation of extracorporeal life support that are predictive of survival for pediatric respiratory failure for whom conventional mechanical ventilation is believed to have failed. These variables indicate that age, duration of mechanical ventilation before ECMO, the degree of oxygenation impairment and ventilator pressure are important predictors of survival.

An optimistic view is that the present technology of extracorporeal life support and current patient management practices with this technology for pediatric respiratory failure may not yet have reached a steady state in terms of optimal patient survival. ${ }^{8,27}$ 


\section{Neonates}

The use of extracorporeal life support for neonatal respiratory failure has progressed from laboratory studies to initial clinical trials to routine clinical practices. The first succesful case was treated in 1975 and reported in 1976 and clinical experience gradually increased over the next several years. By 1985, there were 18 centers using and evaluating ECMO for newborn infants. A central registry was established and experience with 715 cases were reported in $1988 .^{28}$ Two prospective randomized studies were carried out using adaptive designs, both of which demonstrated that extracorporeal support offered better survival than conventional treatment of the time. In 1988, the Extracorporeal Life Support Organization (ELSO) was organized to standardize the treatment, maintain the central data registry, and document and control the growth of the technology in and organized fashion. In 1979, the National Institute of Health held a workshop on the diffusion of high-tech medicine into general clinical practice using neonatal ECMO as the prototypic example. The workshop was held in 1990 and published in 1993. The conclusions from the 1990 workshop were that neonatal ECMO was established as standard treatment for severe respiratory failure unresponsive to other methods of management.

Presently over 4.700 neonates have been treated with extracorporeal life support since 1984, with an overall cumulative survival rate for all respiratory diagnoses $83 \%$ as of 1991. In 10- year time (1979-1989) aspiration syndrome was shown to benefit most from ECMO, risk of mortality was reduced from $80 \%$ (based on historical control) to about $7.5 \%-9 \%$.

Respiratory distress syndrome was shown to have $83 \%$ survival rate, while in pulmonary hypertension of the newborn and air leak syndrome the rates were $87 \%$ and $60 \%$, respectively. Interestingly sepsis/pneumonia also could benefit from this kind of intervention with survival rate $77 \%$ but ECMO has made only modest improvements in the survival rate of neonates with congenital diaphragmatic hernea; from neonatal patients with $\mathrm{CDH}$ of the Extracorporeal Life Support organization registry (1980-1992), the survival rate with ECMO is $62 \%$.

There has been concern that carotid ligation may be associated with late secondary cerebral ischemia. Infants should be followed with routine neuro-developmental and medical evaluation. The follow-up studies to date report an extremely encouraging $70 \%$ to $80 \%$ of children with normal development. ${ }^{12}$ Results from
(Bartlett) were reported in 1994 recounting the experience with 460 newborn cases over 20 years with overall $87 \%$ survival. The worldwide experience recorded in the neonatal ECMO registry in 1994 should a $81 \%$ survival of 9258 cases later and documented in Table 2 . The registry report appears annually in the meeting edition of the Journal of ASAIO.

Table 1. Outcome in neonatal respiratory failure treated with ECLS. University of Michigan data

\begin{tabular}{lcc}
\hline & No of Cases & \% Survival \\
\hline MAS & 170 & 97 \\
RDS & 91 & 88 \\
PFC & 38 & 92 \\
CDH & 68 & 66 \\
Sepsis & 78 & 83 \\
Other & 24 & 75 \\
& & \\
\hline Total & 469 & 87 \\
\hline \multirow{2}{*}{ MAS } & $=$ meconium aspiration syndrome. \\
RDS & $=$ infant respiratory distress syndrome. \\
PFC & $=$ persistent fetal circulation. \\
CDH & $=$ congenital diaphragmatic hemia. \\
Sepsis & $=$ neonatal sepsis.
\end{tabular}

Table 2. Outcome in neonatal respiratory failure treated with ECLS. ELSO Registry data ${ }^{29}$

\begin{tabular}{lcc}
\hline & No of Cases & \% Survival \\
\hline MAS & 3395 & 93 \\
RDS & 1051 & 84 \\
PFC & 1209 & 83 \\
CDH & 1808 & 58 \\
Sepsis & 1431 & 76 \\
Other & 321 & 78 \\
\hline Total & 9258 & 81 \\
\hline
\end{tabular}

\section{ANTICOAGULATION, ARTIFICIAL LUNGS, AND PUMPS}

Due to continuous heparinization, bleeding has been the major problem with ECMO. In adult the introduction of percutaneus cannulation has lessened the bleeding from the cannulation site.

\section{Anticoagulation}

In neonates and pediatric population there is a tendency to maintain lower activated clotting time (from $200-240 \mathrm{msec}$ to $180-200 \mathrm{msec}$ ), and a higher platelet 
count (from $>50.000-600 / \mu \mathrm{l}$ before 1988 to more than $100.000 / \mu \mathrm{l}$ recently). Surface heparinized circuits that could be run without systemic anticoagulation and at normal clotting times are being tested and are recently become available. One report has described the use of this technique in a patient who underwent succesfull extracorporeal lung assist for 35 days despite discontinuing intravenous heparin because of severe bleeding after the first 14 days. ${ }^{30}$

There are two types of pumps which are being used for extracorporeal life support, i.e., centrifugal pump and roller pump. Most centers are using roller pump but centrifugal pump become increasingly popular. Almost all centers exclusively used Scimed Kolobow spiral silicon rubber membrane lungs. These lungs are good for long term use, some have lasted uninterruptedly for more than 3 weeks with satisfactory gas exchange performances. They routinely last well over a week. Membrane lung leakage is extremely rare with this device.

Microporous fiber lungs with heparin surface coating are now available, but the major disadvantage of this device is plasma leakage. The hydrophobic pores, after a certain time of contact with blood, become hydrophilic and start to leak plasma at variable rates. A very new microporous fiber lungs with less plasma leakage is now available.

A new protease inhibitor, nafamostat mesylate has been developed as a short life anticoagulation and has been widely used to control blood coagulatin during treatment with artificial organs, however further experimental trials will be needed to determine whether anticoagulation with nafamostal mesylate is superior to standard anticoagulation using heparin in ECMO. ${ }^{31}$

\section{COMPLICATIONS AND COST}

As with every technology advance, the benefits of an invasive intervention must be weighed against the risk. Due to the systemic heparinization, the risk for hemorrhage is very great. Intracranial bleeding in the neonates is the most devastating complication and contributes to the mortality and the neurologic morbidity. ${ }^{12}$ Other complications are brain death, systemic hypertension, sepsis, and also cerebral infarction. ${ }^{16,17}$ Mechanical complications such as oxygenator failure, raceway rupture, pump malfunction, clots and air in circuit, and cannula malposition can occur. ${ }^{24,32}$ At our institution one of our ECMO deaths was attributed to a raceway rupture.
The cost of health care has become a pressing concern, high technology intensive care interventions are often singled out as an important factor contributing to escalating cost. ECMO falls into this category and representing one of the most exciting and effective technologies developed in the past 25 years especially in newborn intensive care. Pearson and Short examined hospital charges for infants who met criteria for ECMO in the years before and after an ECMO program began. When they considered all infants, ECMO was 2 percent less expensive than conventional treatment. When only survivors were considered, ECMO was 43 percent less costly. Per diem hospital charges for conventionally treated infants were 57 percent of per diem charges for infants treated with ECMO. So, the overall cost differences were attributable to a reduction in the average length of the hospital stay in the group that received ECMO. ${ }^{33}$

Added daily cost of ECCO2R (adult) to the patient amount to approximately 4500 USD for the initation of bypass and approximately 2500 USD a day while being maintained on bypass. In Milan, Italy added daily cost is around 1000 USD and in Melbourne, Australia 1000 Australian dollars. ${ }^{34}$ Our recent experiences with a 3 year-old child who was on bypass (ECMO) for 5 days, the total cost was 10.500 USD (1500 USD/day for disposable and laboratory tests, 3000 USD the initiation of bypass).

Care of the patient on ECMO requires attendance of ECMO personnel. These personnel are doctors/nurses, perfusionist, who are specially trained in the class room and in the laboratory. They work in conjunction with the patients nurse to carry out all the patients needs. Team work from intensivist, neonatologist, surgeons, and technicians as well as consultants (cardiologist, pulmonologist) is essential. ${ }^{35}$ The total cost of developing an ECMO program averages 125.000 USD, with a range of 50.000 USD to 200.000 USD. (equipment $30.000 \mathrm{USD}$ ) and training costs represent the mayority of the expense incurred for operating budget. One of the major expense is for the personnel (salaries and wages). Fortunately all of our personnel are still working voluntarily for this program. We also have cut our training cost by joining a 2 weeks ECMO course in Melbourne - Australia (for 4 personnel 2 doctor, 2 nurses, the total cost was 8000 USD).

ECMO as a part of an extension therapy of mechanical ventilation is a major challenge faced by developing countries such as Indonesia. Apart from financial constraints, experience shows that to institute ECMO for 
patients who already has an indication, and convincing their doctors of the effectiveness of ECMO is not easy, until it is too late when the patients have already had an irreversible organ damage. Like other sophisticated and high technologies, the ECMO could only be offered at certain hospitals. For setting up such program, lacking of experienced staff in cardio-pulmonary bypass (cardiac surgery) is one of the main obstacles.

The ECMO program in "Harapan Kita" National Cardiac Center Indonesia (a cardiac hospital with 600 open heart surgeries per year) has been started since 1991. Due to the constraints such as funds, logistics, and difficulties in obtaining referral (the patient is delivered late or the patient has no indication), we were only able to handle 9 ECMO cases (circulatory support or pulmonary support whithin 3 years time) with only 2 neonate ECMO survivor (decannulated).

It is recomended that a minimum of 12 patients per year be treated in order to ensure that clinical skills are maintained for this complicated therapy. However, thanks to the development in technology (heparin bonded oxygenator/circuit) we are very optimistic (even in a developing countries) for the future of ECMO as long as it is done for neonatal respiratory failure, at 1- or 2 selected centers and always taking into the consideration "the cost benefit analysis" and "cost effectiveness analysis"

Although important questions remain unanswered, certain indications for the use of ECMO are widely accepted, and areas of research are well-defined, and as with other innovative therapy, a desire for rigid rules and for a clearer demarcation between standard and experimental therapy may be unwise and unrealistic. ${ }^{32}$ Decisions about innovations in clinical medicine remains matters of practical wisdom, rather than of theoretical science.

\section{REFERENCES}

1. Gibbon JH. Artificial maintenance of circulation during experimental occlusion of pulmonary artery. Arch Surg 1937,34:1105-31.

2. National Heart, Lung and Blood Institute, Division of Lung Disease. Extracorporeal support for respiratory insufficiency: a collaborative study in response to RFP-NHHL 73-20. Besthesda MD National, Heart Lung and Blood Institute 1979:1-395.

3. Zapol WM, Snider MT, Hill JD et al. Extracorporeal membrane oxygenation in severe acute respiratory failure: a randomized prospective study. JAMA 1979; 242:2193-6.

4. Hill JD, O'Brien TG, Murray JJ, et al. Acute respiratory insufficiancy. J Thorac Cardiovasc Surg 64:551,1972.
5. Gattinoni L, Pesenti A, Damin G. Extracorporeal carbon dioxide removal. In: Textbook of critical care, 2 nd ed. Saunders, 1989-656.

6. Anderson HL, Delius RE, Sinard JM, et al. Early experience with adult extracorporeal membrane oxygenation in the modern era. Ann Thorac Surg 1992;53:553.

7. Egan TM, Duffin J, Glyin MFT, et al. Ten year experience with extracorporeal membrane oxygenation for severe respiratory failure. Chest 1988;94:681.

8. Muller E, Knoch M, Moltermann, Lennarts. Extracorporeal respiratory support $\left(\mathrm{ECCO}_{2} \mathrm{R}\right)$ in severe acute respiratory failure (ARDS), Medicine intensive. The $6^{\text {th }}$ World Congress on Intensive and Critical Care Medicine. 1993. Abstract 80.521.

9. Hickling $\mathrm{KG}$. Extracorporeal $\mathrm{CO}_{2}$ removal in severe adult respiratory distress syndrome. Anaesth Intensive Care, 1986;14:46-31.

10. Morioka $\mathrm{T}$, Terasuki $\mathrm{H}$, Tsuno $\mathrm{K}$ et al. Indication and methods of extracorporeal lung assist (Ecla as ECMO). Presented at the $4^{\text {th }}$ Congress of Western Pacific Association of critical care medicine (WPACCM), Denpasar, September 6-9, 1987.

11. Gattinoni L, Pesenti A, Bombino $\mathrm{M}$ et al. Extracorporeal carbon dioxide removal in contemporary management in critical care, mechanical ventilation and assisted respiration. In: Grenvik A, Downs JB, Rasaneu J, Smith R eds. New York: Churchill Living Stone, 1991:91-113.

12. Fuhrman BP, Dalton HJ. Progress in pediatric extracorporeal membrane oxygenation Crit Care Clin 1992;8:191-201.

13. Gattinoni L, Pesenti A, Marcolin R et al. Extracorporeal support in acute respiratory failure. Intensive Care World 1988;5:42-45.

14. Bartlett RH, Roloff DW, Comell RG et al. Extracorporeal circulation in neonatal respiratory failure. A prospective randomized study. Pediatrics 1985;76:479.

15. Anderson III HL, Attori RJ, Custer JR, Chapman RA, Barlett RH. Extracorporeal membrane oxygenation for pediatric cardiopulmonary failure. J Thorac Cardiovasc Surg 1990;99:1011.

16. Kirkpatrick BV, Krammel TM, Mucller DG, Ormazabal MA, Greenfield LJ, Salzberg AM. Use of extracorporeal membrane oxygenation for respiratory failure in term infants. J Pediatr 1983; $72: 872$.

17. Chevolier JU, Durandy Y, Batisse A, Mathe JC, Lostil J. Preliminary extracorporeal lung support for the neonatal adult respiratory failure. Lancet 1990;335:1364.

18. Horton SB, Horton AM, Mullaly RJ et al. Extracorporeal membrane oxygenation life support a new approach. Perfusion 1993;8:239-247.

19. Oritz RM. Pediatric Clinical 1987;34:39.

20. Barlett RH. Current status of extracorporeal life support in neonatal respiratory failure. Yeas Book of Intensive Care and Emergency Medicine. Springer 1995:209-17.

21. Morris AH, Suchyta. Extracorporeal $\mathrm{CO}_{2}$ removal for ARDS. Crit Care Res 1990;1:184.

22. Lewandawski, Falke KJ. An imperative for scratinizing extracorporeal membrane oxygenation. Curr Opin Crit Care $1995 ; 1: 62-70$. 
23. Dembitsky WP, Willem DC, Jaski BE. Peripheral vascular access for organ support in extracorporeal cardiopulmonary support in critical care. Edited by Zwischenberger JB, Bartlett RH. Extracorporeal Life Support Organization 1995. Ann Arbor 1995;205-19.

24. Dellius RE, Bove EL, Meliones JN et al. Use of extracorporeal life support in patients with congenital heart disease. Crit Care Med 1992;20:1216-22.

25. Redmond CR, Graves ED, Falterman KW, Ochner JL, Arens RM. Extracorporeal membrane oxygenation for respiratory and cardiac failure in infants and children. J Thorac Cardovasc Surg 1987; 93:199.

26. Kanter KR, Reuning DG, Weber TR, Zambie MA, Braun P, Martychenkov. Extracorporeal membrane oxygenation for postoperative cardiac support in children. J Thorac Cardiovasc Surg 1987; 93:27-35.

27. Thomas P. Green, Otwel, James C, et al. The impact of extracorporeal membrane oxygenation on survival in pediatric patients with acute respiratory failure. Crit Care Med 1996;24:323-9.

28. Toomsian JM, Snedecor SM, Cornell RG, Cilley RE, Bartlett RH. National experience with extracorporeal membrane oxygenation for newborn respiratory failure. ASAIO Trans 1988;34:140-7.

29. Tracy TF, De Losh T, Bartlett RH. Registry Report. Extracorporeal Life Support Organization 1994. Am Soc Artif Intern Organs.

30. Wetterberg T, Steen S. Total extracorporcal lung assist a new clinical apporoach. Int Care Med 1991;17:73-7.

31. Anderson HL, Edmunds Jr. Coagulation, anticoagulation and the interaction of blood and artificial surfaces in extracorporeal cardiopulmonary support in critical care, Edited by Zwischenberger JB, Bartlett RH. Extracorporeal Life Support Organization 1995. Ann Arbor 1995; 53-70.

32. Vagler C, Avila C, Lagunoff D. Alumunium containing emboli in infants treated with extracorporeal membrane oxygenation. N Engl J Med 1988:2:75-9.

33. Lantos JD, Frader J. Sounding board extracorporeal membrane oxygenation and the ethics of clinical research in pediatrics. N Engl J Med 1990; 9:409.

34. Butt W. Personal communication.

35. Ortiz. RM, Cilley RE, Barlett. Extracorporeal membrane oxygenation in pediatric respiratory failure. Pediatr Clin North Am 1987; 34:39-45. 